\title{
Use of natural substrates as an alternative for the prevention of microbial contamination in the food industry
}

\author{
Giovana Rueda BARBOZA ${ }^{1}$, Jaqueline Milagres de ALMEIDA $^{1}$, Nathália Cristina Cirone SILVA ${ }^{1 *}$ (D)
}

\begin{abstract}
The use of additives by the food industry is a way to prevent bacterial and fungal contamination in products as well as to conserve foods during their shelf life, preventing them from causing diseases or undesirable alterations in the sensory characteristics of foods. Food producers are greatly concerned about decreasing the addition of synthetic compounds, to avoid harm to the consumer's health and to the environment and, at the same time, about contributing to the maintenance of a safe food.
\end{abstract}

Keywords: food safety; natural substrates; pathogenic microorganisms; spoilage.

Practical Application: The overview about the use of natural products allows understanding this use for controlling microbial contamination in food.

\section{Introduction}

For many years, technological advancement has been very important for food processing because it increases food shelflife, avoiding waste and improving the availability of nutrients to the consumer (Asioli et al., 2017). In recent decades, enthusiasm has been observed in the use of natural resources for food and industrial processes. Due to the new alternative eating style, many studies seek methods for extraction of natural substrates that can replace synthetic additives in food production (Santos et al., 2018). Natural substrates are compounds present in plants, bacteria, fungi and mushrooms, and the most common ones are bacteriocins, fungal metabolites, mono- and sesquiterpenes, phenylpropanoids, bioactive compounds, and essential oils.

Pathogenic or spoilage microorganisms can be transmitted by food and water; therefore, the use of additives becomes important for conservation during food production, storage and consumption to prevent transmission of foodborne diseases to consumers and unwanted deterioration. The presence of fungi and bacteria in food causes loss of net turnover in the food industry and in agriculture besides the loss of credibility and quality of products.

Foodborne diseases (FBD) are caused by food or water intake, an important cause of morbidity and mortality worldwide. Most of them are infections caused by bacteria, toxins, viruses, and parasites. A FBD outbreak can be characterized when two or more people contract the disease after they ingest food or water from the same environment (Pinheiro et al., 2010; Brasil, 2019).

This is something worrisome because, according to data from SVS (Brazilian health surveillance secretariat), 598 FBD outbreaks were notified in 2017, with 9,426 sick people, 1,439 hospitalized people and 12 related deaths. According to these notifications, residences were the place with the highest occurrence of FBD outbreaks from 2009 to 2018 (Brasil, 2019).

Because of these facts, using preservation methods is important to reduce these outbreaks. The addition of preservatives is a solution to reduce food deterioration by bacteria or intrinsic and extrinsic factors, because these deteriorations cause undesirable flavors and odors and loss of nutritional value. The use of extracts from natural products for this preservation has been widely studied for being a healthier alternative (Santos et al., 2018).

Consumers' interest in healthier and organic foods, with fewer preservative additives and closer to natural has driven researchers and food industries to reconsider their methods for conservation, protection, safety and quality of products, exploring the efficiency of natural antimicrobials (Taylor, 2018). The application of natural products to foods, to the detriment of the use of chemical and synthetic additives, both at the processing and at the packaging stages, has been achieving promising results regarding efficiency of inhibition and methods of application (Millezi et al., 2014; Cordery et al., 2018).

According to Taylor (2018), natural antimicrobials can be used in several types of processing during the production of foods, such as thermal and nonthermal processes, with the application of high pressure in the inhibition of microorganisms. They have also been incorporated into packaging and edible films/coatings and subjected to encapsulation in micro and nano scales, to improve the efficacy of the antimicrobial action or release in the products. In contrast, the use of essential oils have some limitations such as sensory alteration, miscibility problems, interactions with the components of the food matrix, in addition to depending on factors such as temperature and 
pH of the food (Mendonça et al., 2018). Thus, the encapsulation is shown as a viable alternative to overcome these limitations.

\section{Plant products}

Some natural antimicrobials used for food preservation, as well as for inhibition of growth of spoilage and pathogenic microorganisms, come from plants and are used in the form of essential oils (EOs) (Taylor, 2018). EOs are complex mixtures that can contain about 20 to 80 individual components (Mendonça et al., 2018) and several aromatic compounds and be defined as lipophilic and complex volatile substances, which are usually odorous and liquid, originating from the secondary metabolism of plants. Chemically, EOs are composed of terpene compounds, alcohols, acids, esters, epoxide, aldehydes, ketones, amines, and sulfides (Bakkali et al., 2008; Millezi et al., 2014). They can be extracted from different raw materials such as: plant leaves, roots, fruits, stems, barks, etc. (Erasto et al., 2004; Rahman \& Gray, 2002; Zhu et al., 2004). Some commonly used plants are: cinnamon, thyme, rosemary, oregano, basil, and clove (Mendonça et al., 2018). They can be obtained from methods such as distillation and cold pressing (Mendonça et al., 2018).

The main substances used are mono- and sesquiterpenes, phenylpropanoids, and bioactive compounds. Studies show laurel, marjoram, basil, carnation, coriander, lemon balm, and lemon have antimicrobial action (Santos et al., 2018).

In Campinas, a study was conducted using leaves of Nardus and S. Montana and barks of C. Limonia, to analyze the antimicrobial action of E. Coli and S. aureus. S. aureus had a greater sensitivity to C. Limonia; and E. Coli, to oil from S. Montana. In vitro results suggest the potential use of these oils as antimicrobials and preservatives (Millezi et al., 2014).

Another study conducted in Bahia used essential oil from Eucalyptus urograndis capsule and analyzed the antimicrobial action of Staphylococcus aureus ATCC12692, Streptococcus pyogenes ATCC 19615, Proteus mirabilis ATCC 7002, Klebsiella pneumoniae ATC BAA-1706, and Escherichia coli ATCC 29214 using disk diffusion. This essential oil was efficient against Staphylococcus aureus (Alcântara et al., 2019).

\section{Mechanism of antimicrobial action of essential oils}

EOs are able to inhibit microbial growth, causing bacteriostatic and bactericidal effects and have inhibitory activity against fungi and yeasts (Lang \& Buchbauer, 2012), through physical, chemical or biochemical alterations in microorganisms (Rao et al., 2019).

The solubility in water of the constituents of EO is directly related to its ability to penetrate the cell wall of fungi and cell membrane of bacteria. However, the antimicrobial activity depends on the concentration and on the types of chemical constituents present in the EOs; therefore, they will have different mechanisms of action in different microorganisms, acting mainly through the solubility in the lipid bilayer of the cell membrane (Knobloch et al., 1989; Suppakul \& Bandyopadhyay, 2002; Rao et al., 2019).

Among the constituents of the essential oils, the phenolic compounds act through the permeability of the membrane of the microbial cell, interacting with membrane proteins, changing its function and structure, and inducing the loss of biomolecules of the interior of the cell. They also influence electron transport, enzymatic activity, protein synthesis, and nucleic acids (Bajpai et al., 2008; Gyawali \& Ibrahim, 2014). In addition, the antimicrobial activity of the phenolics depends on the concentration. At low concentration, it inhibits the enzymatic activity, and, at higher concentrations, it induces protein denaturation (Gyawali \& Ibrahim, 2014).

Lipid compounds act through the rupture of the bacterial cell membrane, preventing DNA replication (Pisoschi et al., 2018). Unsaturated fatty acids have a stronger inhibitory effect when compared with saturated fatty acids (Desbois \& Smith, 2010); (Gyawali \& Ibrahim, 2014); thus, Desbois \& Smith (2010) showed medium- and long-chain fatty acids were more effective against Gram-positive bacteria than against Gram-negative bacteria.

Some studies conclude that Gram-positive bacteria are more susceptible to the antimicrobial action of EOs and extracts compared with Gram-negative bacteria, since the former does not have a protective external membrane, but Rao et al. (2019) these studies highlight that EOs may have different mechanisms of action due to the variation in the composition of cell membranes of different microorganisms.

For being composed of peptidoglycan, teichoic acid, and proteins, the cell wall structure of Gram-positive bacteria allows the penetration of hydrophobic compounds acting on the wall and in the cytoplasm. Essential oils bind to enzymes, decreasing energy production and denaturating proteins. The cell wall of Gram-negative bacteria is more complex. It has a thin layer of peptidoglycan and an external membrane (OM), which are covalently bound by Braun's lipoprotein (Nazzaro et al., 2013). However, Bajpai et al. (2012), Burt (2004), Kim et al. (2011) and Nazzaro et al. (2013) showed several EOs are effective with Gram-negative bacteria.

Zhang et al. (2016) observed the antimicrobial activity of cinnamon EO against Escherichia coli and Staphylococcus aureus with minimum inhibitory concentration (MIC) of $1.0 \mathrm{mg} / \mathrm{mL}$ of EO for both bacteria, and the minimum bacterial concentration (CBM) was $4.0 \mathrm{mg} / \mathrm{mL}$ for $E$. Coli and $2.0 \mathrm{mg} / \mathrm{mL}$ for S. aureus. Moreover, scanning electron microscopy was used to elucidate the mechanism of action of cinnamon EO, and morphological alterations in the cell wall of $E$. Coli and S. aureus,such as irregular forms and swelling, were observed. This was due to increased permeability of the cell membrane, causing cellular leakage of electrolytes verified by the electrical conductivity of cells, in which $S$. aureus was more sensitivefor its higher electrical conductivity after treatment with the MIC of EO, whereas the electrical conductivity of $E$. Coli was lower. An increase in the concentration of proteins and nucleic acids in suspension was also observed.

Dannenberg et al. (2019) verified the antimicrobial action and mechanism of action of pink pepper EO against Staphylococcus aureus and Listeria monocytogenes, whose MIC were 0.68 and $1.36 \mathrm{mg} / \mathrm{mL}$, respectively, and CBM was $2.72 \mathrm{mg} / \mathrm{mL}$ for each of the bacteria. The oil also reduced the growth of Escherichia coli and Salmonella Typhimurium to 16 and 15\%, respectively. 
They also found alterations in the permeability and integrity of the cell membrane of all bacteria, showing that cell wall damage is one of the mechanisms of action of the pink pepper oil.

\section{Bacteriocins}

Natural extracts are more widely used than synthetic antimicrobials in some countries, such as Nigeria. They are widely used to inhibit the growth of fungi and yeasts, considering their $\mathrm{pH}$. Natural antimicrobials extracted from plants, animals or microorganisms are being increasingly used in natural food preservation and as flavoring agents in some foods.

Bacteriocins have been recognized as a potential source of food biopreservatives and can be used for food safety of several types of foods by inhibiting undesirable microflora. Bacteriocins are peptides that are inserted into the cell membranes to form pores, inhibiting the synthesis of peptidoglycan and DNA replication (Mantovani et al., 2002).

Bacteriocins are heat-stable and efficient at physiological $\mathrm{pH}$. The application of bacteriocin can be chosen due to its properties: temperature stability, $\mathrm{pH}$ and action spectrum (Moreno et al., 1999; Ross et al., 1999).

The activity of bacteriocins in food may be affected by change in solubility and electrostatic charge, binding to food components, inactivation by proteases, changes in the cell wall or membrane of the target microorganisms, salt concentration, $\mathrm{pH}$, nitrite and nitrate, aqueous phase available for diffusion, lipid content and lipid surface available for solubilization, amount of antimicrobial required for this activity (Gänzle et al., 1999; Blom et al., 1997).

Bacteriocins produced by lactic acid bacteria are frequently isolated from fermented foods (Stoffels et al., 1992).

In biotechnology, bacteriocins are used directly in fruitderived products (Barbosa et al., 2017).

\subsection{Nisin}

Nisin is a peptide extracted from Lactococcus lactis, bacteria that are common in milk due to their ability to ferment sucrose. This bacteriocin is ribosomally produced, belonging to the class of lantibiotics and to the subclass Ia, being identified by the INS as E234. This is the only bacteriocin approved by the FDA (Food and Drug Agency) since 1988, and it is efficient against S. aureus, L. monocytogenes, A. Acidoterrestris, Clostridium, Bacillus and some Gram-negative bacteria, acting against vegetative forms and spores (Barbosa et al., 2017).

The nisin molecule contains 34 amino acids, among which the $\mathrm{NH} 2$ and $\mathrm{COOH}$ terminal amino acids are isoleucine and lysine, respectively. Enzymatic modifications occur to obtain an active form of nisin, removing the leading region, dehydrating the serine and the threonine of the structural region, which forms dehydroalanine and dehydrobutirine. In sequence, thioether bridges are formed by condensation of dehydroalanine and dehydrobutirin with cysteine, producing the amino acids lantionin and $\beta$-methyl-lantionin. The mechanism of action of nisin occurs by the interaction with phospholipids of the plasmatic membrane, forming pores that cause the intracellular material to efflux (Jeong \& Ha, 2018).

Nisin is a potential biopreservative, but its antimicrobial spectrum is limited. Therefore, using barrier technology, changing environmental conditions or adding chelating agents is necessary to increase their action (Silva et al., 2018).

\subsection{Bovicin HC5}

They are bacteriocins produced by Streptococcus bovis strains and have structures similar to lantibiotics, but their use is not approved because they are toxic in dosages close to the concentrations required for their biological activity (Barbosa et al., 2017). The antibacterial activity of the S. Bovis HC5 is a bacteriocin that can be precipitated by ammonium sulfate and inactivated by Pronase E, a mixture of proteinases and peptidases (Mantovani et al., 2002).

In a study by Mantovani et al. (2002), they showed the crude extracts were resistant to $\alpha$-chymotrypsin, proteinase $\mathrm{K}$ and heat, and these properties can be advantageous for commercial applications. The crude extract catalyzed the potassium efflux of S. Bovis JB1, which seemed to contain a pore-forming peptide.

Bacteriocins are associated with detergents that are often added to the culture medium to release bacteriocin and may be precipitated from the cell-free supernatant by ammonium sulfate, but various contaminant peptides were observed (Mantovani et al., 2002).

Another study conducted by Yang et al. (1992), observed bacteriocins of some lactic acid bacteria could be isolated from the cell surface by acid $\mathrm{NaCl}$, releasing $\mathrm{S}$. bovis bacteriocin $\mathrm{HC} 5$ without causing cellular lysis.

\section{Products from fungi}

Fungal metabolites are another type of natural preservative that has been used. For being a low-toxicity product, its use in the agrochemical industry aims to control pests and plant diseases (Dayan et al., 2009).

Endophytic fungi promote the growth of plants by modifying the structure and physiology of the plant while extracting nutrients for itself (Peixoto-Neto et al., 2002).In a recent study, the antibacterial activity of the fungal extract against multiple drug-resistant $S$. aureus strains was efficient (Use et al., 2014).

The genus Phomopsis has secondary metabolites with antimicrobial activity against various pathogenic agents, such as Mycobacterium tuberculosis, E. Coli, Klebsiella pneumoniae, B. Subtilis, Micrococcus luteus and Candida albicans (Jayanthi et al., 2011). Aspergillus fumigatus has metabolites with antifungal activity similar to the commercial fungicides carbendazim and himexazol, against the phytopathogens B. cinerea, Alternaria alternata, C. gloeosporioides, Fusarium oxysporum, F. solani, and Gibberella saubinettii (Li et al., 2012).

The metabolite of Cordyceps dipterigena is efficient in controlling the phytopathogen G. Fujikuroi (Varughese et al., 2012). The extract of Nigrospora sp., found in the root of the medicinal plant Moringa Oleifera, obtains an antibiotic called 
Griseofulvina, which has activity against the phytopathogenic fungi Botrytiscinerea, C. orbiculare, F. oxysporum, Pythiumultimum, Rhizoctoniasolani, and Sclerotiniasclerotium (Zhao et al., 2012).

A study on mushroom extracts and their extracts with antimicrobial activities was carried out. These extracts were used in Staphylococcus aureus (ATCC 25923), Bacillus subtilis (ATCC 6633), Bacillus cereus (ATCC 10987), Escherichia coli (ATCC 25922) e Proteus mirabilis (ATCC 12453), Aspergillus flavus (ATCC 9170), Aspergillus niger (ATCC 16888), Cândida albicans (ATCC 10259), Penicillium expansum (ATCC 20466), Penicillium chrysogenum (ATCC 10106), Mucor Mucedo (ATCC 20094), Trichoderma viride (ATCC 13233), Cladosporium cladosporioides (ATCC 11680), Fusarium oxysporum (ATCC 62506), and Alternaria alternate (ATCC 36376). The result obtained was that the mushroom methanol extract has a stronger antimicrobial effect than that of other extracts.

The mechanisms of antimicrobial action of mushrooms are the inhibition of synthesis of the cell wall, of proteins or of nucleic acids, such as antibiotics. Differences were observed in the antimicrobial activity of the mushrooms tested, which resulted from the presence of different components with antimicrobial activity.

The extracts are mixtures of natural compounds, and their antimicrobial activity may result from their interactions. The sensitivity was different between fungi and bacteria, which can be explained by the cell wall of each microorganism. The cell wall of Gram-positive bacteria contains peptidoglycan (mureins) and teichoic acids, the cell wall of Gram-negative bacteria consists of lipopolysaccharides and lipopolyproteins, and the cell wall of the fungi consists of polysaccharides such as hitchin and glucan (Ranković, 2015).

\section{Marine product}

Chitosan is extracted from crustaceans, show antifungal action, and has been used in fruit and vegetable packaging, in seed treatment (Kulawik et al., 2019), as well as in the encapsulation of antimicrobial agents.

The marine actinobacterium of the genus Verrucosispora from the ocean-bottom sediment produces the polycyclic antibiotic abissomycin $\mathrm{C}$, which inhibits the biosynthesis of the p-aminobenzoic acid. By trapping the target enzyme by Michael reaction, which is a proton abstraction reaction, a nucleophilic attack occurs at the $\beta$ carbon (Bister et al., 2004).

Marine actinobacteria Marinispora produce, in saline culture, A-D marinomicins as well as macrolides with conjugated tetraene-penta-hydroxy-polyketide chains with antibiotic activity against methicillin-resistant Staphylococcus aureus and vancomycin-resistant Enterococcus faecium (Kwon et al., 2006).

\section{Use of natural antimicrobials in technology}

Different applications for natural antimicrobials are considered in the food industry, both as preservatives in packaging and in the food matrix itself as sanitizers of surfaces and equipment. Considering this scenario, Budri et al. (2015) tested essential oils of garlic and cinnamon and its main components, eugenol and cinnamaldehyde, for the prevention of biofilm formation on polystyrene and stainless steel surfaces by Staphylococcus aureus. Using garlic and cinnamon essential oil, as well as cinnamaldehyde, the main component of cinnamon essential oil, they observed significant reduction in the formation of biofilms on the surfaces tested. Eugenol, the main component of garlic essential oil, was less effective compared with the compounds tested.

Another tendency is the use of nanoemulsions of essential oils in foods, which contributes to improved oil dispersion throughout the food matrix, reducing the sensory impact and contributing to food preservation. Donsì \& Ferrari (2016) highlight that the efficacy of essential oils in nanoemulsions depends heavily on the components of the EO, on the type of microorganism tested and on the nanoemulsion formulation and size. Therefore, different formulations of EO nanoemulsions result in effects and in the inhibition of different microorganisms, such as Gram-positive and Gram-negative bacteria, fungi, and yeasts.

Antimicrobial agents have also been studied the application of these compounds in the form of capsules, for example, in packages, in which the antimicrobial agent is concentrated on the food surface. This application reduces obstruction and preserve sensory characteristics (Tiwari et al., 2009).

A new alternative that has been studied by EMBRAPA is the formation of biofilms to act as a physical barrier between seeds treated with fungicides. In a study analyzing the recovery of viable cells, this technology was shown to be promising, being able to increase the number of nodules in the roots of the plants, thus increasing nitrogen fixation (Plotegher et al., 2017).

Nisin and the product based on pomelo extract and ascorbic acid, commercially known as Biomax $\mathrm{D}^{\circledR}$, has been used as a preservative by the dairy industries, in products such as cheese and cream cheese. In a study conducted in Santa Catarina, Nisin and Biomax $\mathrm{D}^{\oplus}$ had similar anti-listeria activity in fatty products such cream and salami (Biasus et al., 2016).

\section{Conclusion}

According to this review, we can observe many alternatives for production of foods with a safe microbiological standard and without addition of synthetic preservatives. However, many studies are needed to prove that these substances are harmless to the environment and to humans.

\section{References}

Alcântara, A. L., Cardoso, R. C., Souza, F. M., \& Espinheira, M. J. C. (2019). Avaliação da atividade antimicrobiana do óleo extraído da cápsula do Eucaliptus urograndis: uma contribuição significativa para o ramo farmacêutico. Revista Multidisciplinar e de Psicologia, 13(43), 455-468.

Asioli, D., Aschemann-Witzel, J., Caputo, V., Vecchio, R., Annunziata, A., Næs, T., \& Varela, P. (2017). Fazendo sentido das tendências de "rótulo limpo": uma revisão do comportamento de escolha de alimentos do consumidor e discussão das implicações do setor. Food Research International, 99(1), 58-71. http://dx.doi.org/10.1016/j. foodres.2017.07.022. PMid:28784520.

Bajpai, V. K., Baek, K. H., \& Kang, S. C. (2012). Control of Salmonella in foods by using essential oils: a review. Food Research International, 45(2), 722-734. http://dx.doi.org/10.1016/j.foodres.2011.04.052. 
Bajpai, V. K., Rahman, A., Dung, N. T., Huh, M. K., \& Kang, S. C. (2008). In vitro inhibition of food spoilage and foodborne pathogenic bacteria by essential oil and leaf extracts of Magnolia liliflora Desr. Journal of Food Science, 73(6), M314-M320. http://dx.doi.org/10.1111/j.17503841.2008.00841.x. PMid:19241564.

Bakkali, F., Averbeck, S., Averbeck, D., \& Idaomar, M. (2008). Biological effects of essential oils: a review. Food and Chemical Toxicology, 46(2), 446-475. http://dx.doi.org/10.1016/j.fct.2007.09.106. PMid:17996351.

Barbosa, A. A. T., Mantovani, H. C., \& Jain, S. (2017). Bacteriocins from lactic acid bacteria and their potential in the preservation of fruit products. Journal Critical Reviews in Biotechnology, 37(7), 852-864. http://dx.doi.org/10.1080/07388551.2016.1262323. PMid:28049350.

Biasus, A. P., Chaves, A. P., Silva, W. P., Luz, C., \& Schittler, L. (2016). Avaliação da multiplicação de Listeria monocytogenes e da atividade antimicrobiana do Biomax D ${ }^{\oplus}$ em nata. Revista de Ciências Agrárias, $39(2), 216-221$.

Bister, B., Bischoff, D., Ströbele, M., Riedlinger, J., Reicke, A., Wolter, F., Bull, A. T., Zähner, H., Fiedler, H. P., \& Süssmuth, R. D. (2004). Abyssomicin C: a polycyclic antibiotic from a marine Verrucosispora strain as an inhibitor of the $p$-aminobenzoic acid/tetrahydrofolate biosynthesis pathway. Angewandte Chemie International Edition, 43(19), 2574-2576. http://dx.doi.org/10.1002/anie.200353160. PMid:15127456.

Blom, H., Katla, T., Hagen, B. F., \& Axelsson, L. (1997). A model assay to demonstrate how intrinsic factors affect diffusion of bacteriocins. International Journal of Food Microbiology, 38(2-3), 103-109. http:// dx.doi.org/10.1016/S0168-1605(97)00098-6. PMid:9506275.

Brasil, Secretaria de Vigilância em Saúde - SVS. (2019). Surtos de doenças transmitidas por alimentos no Brasil. Brasília. Retrieved from http://portalarquivos2.saude.gov.br/images/pdf/2019/fevereiro/15/ Apresenta----o-Surtos-DTA---Fevereiro-2019.pdf

Budri, P. E., Silva, N. C., Bonsaglia, E. C., Fernandes Júnior, A., Araújo Júnior, J. P., Doyama, J. T., Gonçalves, J. L., Santos, M. V., FitzgeraldHughes, D., \& Rall, V. L. (2015). Effect of essential oils of Syzygium aromaticum and Cinnamomum zeylanicum and their major components on biofilm production in Staphylococcus aureus strains isolated from milk of cows with mastitis. Journal of Dairy Science, 98(9), 5899-5904. http://dx.doi.org/10.3168/jds.2015-9442. PMid:26142866.

Burt, S. (2004). Essential oils : their antibacterial properties and potential applications in foods a review. International Journal of Food Microbiology, 94(3), 223-253. http://dx.doi.org/10.1016/j. ijfoodmicro.2004.03.022. PMid:15246235.

Cordery, A., Rao, A. P., \& Ravishankar, S. (2018). Antimicrobial activities of essential oils, plant extracts and their applications in foods: a review. Journal of Agriculture and Environmental Sciences, 7(2), 76-89. http://dx.doi.org/10.15640/jaes.v7n2a9.

Dannenberg, G., Funck, G. D., Silva, W. P., \& Fiorentini, Â. M. (2019). Essential oil from pink pepper (Schinus terebinthifolius Raddi): chemical composition, antibacterial activity and mechanism of action. Food Control, 95, 115-120. http://dx.doi.org/10.1016/j.foodcont.2018.07.034.

Dayan, F., Cantrell, C. L., \& Duke, S. O. (2009). Natural products in crop protection. Bioorganic \& Medicinal Chemistry, 17(12), 40224034. http://dx.doi.org/10.1016/j.bmc.2009.01.046. PMid:19216080.

Desbois, A. P., \& Smith, V. J. (2010). Antibacterial free fatty acids: activities, mechanisms of action and biotechnological potential. Applied Microbiology and Biotechnology, 85(6), 1629-1642. http:// dx.doi.org/10.1007/s00253-009-2355-3. PMid:19956944.

Donsì, F., \& Ferrari, G. (2016). Essential oil nanoemulsions as antimicrobial agents in food. Journal of Biotechnology, 233, 106-120. http://dx.doi. org/10.1016/j.jbiotec.2016.07.005. PMid:27416793.

Erasto, P., Bojase-Moleta, G., \& Majinda, R. R. T. (2004). Antimicrobial and antioxidant flavonoids from the root wood of Bolusanthus speciosus. Phytochemistry, 65(7), 875-880. http://dx.doi.org/10.1016/j. phytochem.2004.02.011. PMid:15081287.

Gänzle, M. G., Weber, S., \& Hammes, W. P. (1999). Effect of ecological factors on the inhibitory spectrum and activity of bacteriocins. International Journal of Food Microbiology, 46(3), 207-217. http:// dx.doi.org/10.1016/S0168-1605(98)00205-0. PMid:10100901.

Gyawali, R., \& Ibrahim, S. A. (2014). Natural products as antimicrobial agents. Food Control, 46, 412-429. http://dx.doi.org/10.1016/j. foodcont.2014.05.047.

Jayanthi, G., Kamalraja, S., Karthikeyanb, K., \& Muthumarya, J. (2011). Antimicrobial and antioxidant activity of the endophytic fungus Phomopsis sp. GJJM07 isolated from Mesua ferrea. International Journal of Current Science, 1, 85-90.

Jeong, J. H., \& Ha, S. C. (2018). Crystal structure of nisi in a lipidfree form, the nisin immunity protein, from Lactococcus lactis. Antimicrobial Agents and Chemotherapy, 62(3), e01966-17. http:// dx.doi.org/10.1128/AAC.01966-17. PMid:29311076.

Kim, S., Kang, D., Kim, J., Ha, Y., Hwang, J. Y., Kim, T., \& Lee, S. (2011). Antimicrobial activity of plant extracts against Salmonella Typhimurium, Escherichia coli O157:H7, and Listeria monocytogenes on fresh lettuce. Journal of Food Science, 76(1), M41-M46. http:// dx.doi.org/10.1111/j.1750-3841.2010.01926.x. PMid:21535692.

Knobloch, K., Pauli, A., Iberl, B., Weigand, H., \& Weis, N. (1989). Antibacterial and antifungal properties of essential oil components. The Journal of Essential Oil Research, 1(3), 119-128. http://dx.doi.or g/10.1080/10412905.1989.9697767.

Kulawik, P., Jamróz, E., \& Özogu, F. (2019). Chitosan for seafood processing and preservation. Sustainable Agriculture Research, 36, 45-79.

Kwon, H. C., Kauffman, C. A., Jensen, P. R., \& Fenical, W. (2006). Marinomycins A-D, antitumor-antibiotics of a new structure class from a marine actinomycete of the recently discovered genus "marinispora". Journal of the American Chemical Society, 128(5), 1622-1632. http://dx.doi.org/10.1021/ja0558948. PMid:16448135.

Lang, G., \& Buchbauer, G. (2012). A review on recent research results (2008-2010) on essential oils as antimicrobials and antifungals: a review. Flavour and Fragrance Journal, 27(1), 13-39. http://dx.doi. org/10.1002/ffj.2082.

Li, X.-J., Zhang, Q., Zhang, A. L., \& Gao, J. M. (2012). Metabolites from Aspergillus fumigates, an endophytic fungus associated with Melia azedarach, and their antifungal, antifeedant and toxic activities. Journal of Agricultural and Food Chemistry, 60(13), 3424-3431. http://dx.doi.org/10.1021/jf300146n. PMid:22409377.

Mantovani, H. C., Hu, H., Worobo, R. W., \& Russell, J. B. (2002). Bovicin HC5, a bacteriocin from Streptococcus bovis HC5. Microbiology, 148(11), 3347-3352. http://dx.doi.org/10.1099/00221287-148-113347. PMid:12427926.

Mendonça, A., Jackson-Davis, A., Moutiq, R., \& Thomas-Popo, E. (2018). Use of natural antimicrobials of plant origin to improve the microbiological safety of foods. In S. C. Ricke, G. G. Atungulu, C. E. Rainwater \& S. H. Park (Eds.), Food and feed safety systems and analysis. London: Academic Press.

Millezi, A. F., Baptista, N. N., Caixeta, D. S., Rossoni, D. F., Cardoso, M. G., \& Piccoli, R. H. (2014). Caracterização química e atividade antibacteriana de óleos essenciais de plantas condimentares e medicinais contra Staphylococcus aureus e Escherichia coli. Revista Brasileira de Plantas Medicinais, 16(1), 18-24. http://dx.doi.org/10.1590/ S1516-05722014000100003.

Moreno, I., Lerayer, A. L. S., \& Leitão, M. F. F. (1999). Detection and characterization of bacteriocin-producing Lactococcus lactis strains. Revista de Microbiologia, 30(2), 130-136. http://dx.doi.org/10.1590/ S0001-37141999000200008. 
Nazzaro, F., Fratianni, F., Martino, L., Coppola, R., \& De Feo, V. (2013). Effect of essential oils on pathogenic bacteria. Pharmaceuticals, 6(12), 1451-1474. http://dx.doi.org/10.3390/ph6121451. PMid:24287491.

Peixoto-Neto, P. A. S., Azevedo, J. L., \& Araújo, W. L. (2002). Microrganismos endofíticos: interação com plantas e potencial biotecnológico. Biotecnologia Ciencia \& Desenvolvimento, 29, 62-76.

Pinheiro, M. P., Wada, T. C., \& Pereira, C. A. M. (2010). Análise microbiológica de Tábua de manipulação de alimentos de uma instituição de ensino superior em São Carlos, SP. Revista SimbioLogias, 3(5), 115-124.

Pisoschi, A. M., Pop, A., Georgescu, C., Turcuş, V., Olah, K., \& Mathe, E. A. C. (2018). An overview of natural antimicrobials role in food. European Journal of Medicinal Chemistry, 143, 922-935. http://dx.doi. org/10.1016/j.ejmech.2017.11.095. PMid:29227932.

Plotegher, F., Majaron, R. F., Hungria, M., \& Ribeiro, C. (2017). O uso de biofilmes como barreira física para a proteção de células de rizóbio sem sementes de soja pré-tratadas com fungicida (pp. 617-620). São Carlos: Embrapa Instrumentação.

Rahman, M. M., \& Gray, A. I. (2002). Antimicrobial constituents from the stem bark of Feronia limonia. Phytochemistry, 59(1), 73-77. http://dx.doi.org/10.1016/S0031-9422(01)00423-X. PMid:11754947.

Ranković, B. R. (2015). Lichen secondary metabolites: bioactive properties and pharmaceutical potential (pp. 1-26). Switzerland: Springer International Publishing.

Rao, J., Chen, B., \& Mcclements, D. J. (2019). Improving the efficacy of essential oils as antimicrobials in foods: mechanisms of action. Annual Review of Food Science and Technology, 10(1), 365-387. http:// dx.doi.org/10.1146/annurev-food-032818-121727. PMid:30653350.

Ross, R. P., Galvin, M., McAuliffe, O., Morgan, S. M., Ryan, M. P., Twomey, D. P., Meaney, W. J., \& Hill, C. (1999). Developing applications for lactococcal bacteriocins. Antonie van Leeuwenhoek, 76(1-4), 337346. http://dx.doi.org/10.1023/A:1002069416067. PMid:10532388.

Santos, J. J., Santos, J., Silva, L. L. S., Medeiros, M. R. G., Moura, E. R. R., Santos, A. F. R., Silva, J. C. C., Silveira, A. C. M., \& Viera, V. B. (2018). O uso de óleos essenciais como conservantes naturais em substituição aos conservantes sintéticos: uma revisão. International Journal of Neurology, 11(1), 24-327. http://dx.doi.org/10.1055/s-0038-1674882.

Silva, C. C. G., Silva, S. P. M., \& Ribeiro, S. C. (2018). Application of bacteriocins and protective cultures in dairy food preservation. Frontiers in Microbiology, 9, 594. http://dx.doi.org/10.3389/ fmicb.2018.00594. PMid:29686652.

Stoffels, G., Nissen-Meyer, J., Gudmundsdottir, A., Sletten, K., Holo, H., \& Nes, I. F. (1992). Purification and characterization of a new bacteriocin isolated from Carnobacterium sp. Applied and
Environmental Microbiology, 58(5), 1417-1422. http://dx.doi. org/10.1128/AEM.58.5.1417-1422.1992. PMid:1622206.

Suppakul, P., \& Bandyopadhyay, S. (2002). The effect of weave pattern on the mode-I interlaminar fracture energy of E-glass/vinyl ester composites. Composites Science and Technology, 62(5), 709-717. http://dx.doi.org/10.1016/S0266-3538(01)00220-2.

Taylor, T. M. (2018). Natural food antimicrobials: recent trends in their use, limitations, and opportunities for their applications in food preservation. In X. Fan, H. Ngo \& C. Wu (Eds.), Natural and biobased antimicrobials for food applications. Washington: American Chemical Society.

Tiwari, B. K., Valdramidis, V. P., O’Donnell, C. P., Muthukumarappan, K., Bourke, P., \& Cullen, P. J. (2009). Application of natural antimicrobials for food preservation. Journal of Agricultural and Food Chemistry, 57(14), 5987-6000. http://dx.doi.org/10.1021/ jf900668n. PMid:19548681.

Use, A., Kanugula, K. A., Kotamraju, S., Karunakaran, C., \& Rajendran, A. (2014). Cytotoxic and antibacterial activities of secondary metabolites from endophytic fungus Pestalotiopsis virgatula VN2. Current Research in Environmental \& Applied Mycology, 4(1), 107115. http://dx.doi.org/10.5943/cream/4/1/9.

Varughese, T., Riosa, N., Higginbotham, S., Arnold, A. E., Coley, P. D., Kursar, T. A., Gerwick, W. H., \& Cubilla, R. L. (2012). Antifungal depsidone metabolites from Cordyceps dipetrigena, an endophytic fungus antagonistic to the phytopathogen Gibberella fujikuroi. Tetrahedron Letters, 53(13), 1624-1626. http://dx.doi.org/10.1016/j. tetlet.2012.01.076. PMid:22707798.

Yang, R., Johnson, M., \& Ray, B. (1992). Novo método para extrair grandes quantidades de bacteriocinas de bactérias do ácido láctico. Applied and Environmental Microbiology, 58(10), 3355-3359. http:// dx.doi.org/10.1128/AEM.58.10.3355-3359.1992. PMid:1444369.

Zhang, Y., Liu, X., Wang, Y., Jiang, P., \& Quek, S. Y. (2016). Antibacterial activity and mechanism of cinnamon essential oil against Escherichia coli and Staphylococcus aureus. Food Control, 59, 282-289. http:// dx.doi.org/10.1016/j.foodcont.2015.05.032.

Zhao, J. H., Zhang, Y. L., Wang, L. W., Wang, J. Y., \& Zhang, C. L. (2012). Bioactive secondary metabolites from Nigrospora sp. LLGLM003, an endophytic fungus of the medicinal plant Moringa oleifera Lam. World Journal of Microbiology \& Biotechnology, 28(5), 2107-2112. http://dx.doi.org/10.1007/s11274-012-1015-4. PMid:22806033.

Zhu, X., Zhang, H., \& Lo, R. (2004). Phenolic compounds from the leaf extract of artichoke (Cynara scolymus L.) and their antimicrobial activities. Journal of Agricultural and Food Chemistry, 52(24), 7272 7278. http://dx.doi.org/10.1021/jf0490192. PMid:15563206. 